\title{
Research \\ Monitoring Social Learning Processes in Adaptive Comanagement: Three Case Studies from South Africa
}

\author{
$\underline{\text { Georgina Cundill }}^{1,2}$
}

\begin{abstract}
Learning provides the basis for fostering transitions toward adaptive comanagement. Understanding the ways in which arenas for collaboration and learning are created, and the outcomes of these processes in different contexts, is therefore crucial. This paper presents the results of an experimental research process that identified a small set of key variables that influence effective collaboration and learning, and tested a methodology for monitoring these in a collaborative way in three case studies in South Africa. The small set of key variables tested in this study was sensitive enough to register change over a period of 18 months. Results suggest that the background conditions necessary for social learning can be externally managed during an initiative, with positive outcomes for collaboration and learning. Monitoring outcomes suggest that for learning to be effective, a balance needs to be sought between maintaining key individuals within the system, preventing rigidity and vulnerability when this is achieved, and encouraging active participation within communities of practice. Effective facilitation by an 'honest broker' is one of the ways in which this can be achieved. The results point to an over simplification in the rhetoric that currently surrounds the learning outcomes of multilevel networks, and challenges the idea that democratic structures are necessarily important for effective natural resource management at the community level.
\end{abstract}

Key Words: adaptive comanagement; collaboration; learning; monitoring

\section{INTRODUCTION}

Adaptive comanagement is a governance based approach aimed at dealing with complexity and uncertainty in natural resource management (Ruitenbeek and Cartier 2001), and is often put forward as an approach to more sustainable ecosystem management when faced with complex social-ecological systems (Olsson et al. 2007, Armitage et al. 2009). The approach is increasingly seen as a means to marry the strengths of adaptive and collaborative (co)management through a focus on learning and linkages between actors and organizations operating at multiple levels (Armitage et al. 2007, Olsson et al. 2007). Although a limited set of case studies of adaptive comanagement have emerged from many parts of the world (Marschke and Nong 2003, Doubleday 2005, Kristofferson and Berkes 2005, McConney et al. 2007), by far the most thoroughly studied example is that of the Kristianstads Vattenrike
Biosphere Reserve in Sweden (Olsson et al. 2004a, $b$, 2006, 2007). Based on these studies, adaptive comanagement is thought to rely on processes that build knowledge, create networks between multiple actors, and that foster effective leadership (Olsson et al. 2004a, 2007). However, these processes are founded on the principle that different types of knowledge will be combined and that learning will take place during this process (Folke et al. 2003, Armitage et al. 2009). Indeed, learning provides the basis for fostering the innovation necessary for positive transitions in social-ecological systems (Fazey et al. 2007), and social learning in particular has been shown to facilitate institutional innovation (Kumler and Lemos 2008). Understanding the ways in which arenas for effective learning are created, and the outcomes of these processes for adaptive comanagement, is therefore crucial.

In adaptive comanagement, the expectation is that learning will lead to collective action and 
institutional change in the form of rules, laws, customs, and norms (Pahl-Wostl 2006). The term institution refers to the rules actually in use that regulate people's interactions with ecosystems (Ostrom 1990, 1992). Social learning approaches aim to find ways to enable people to transcend social norms, values, and traditional ways of thinking about problems, to cope with social-ecological change (Wals and van der Leij 2007), and therefore plays a direct role in stimulating institutional innovation.

In the pedagogical literature, social learning has been described as a shift away from transmissive expert-based teaching, and toward transformative community-based learning (Capra 2007). However, there is no universal theoretical basis or terminology for social learning (Wals and van der Leij 2007), which makes it difficult to monitor. Although some place emphasis on learning by individuals in social settings, others refer to learning at the level of the group or society (Parson and Clark 1995). In the field of natural resource management, social learning has been defined as the collective action and reflection that takes place among both individuals and groups when they work to improve the management of the interrelationships between social and ecological systems (Keen et al. 2005). This is the definition adopted in this paper.

However, although it is widely assumed that learning provides the basis for shaping and creating appropriate institutional structures for dealing with uncertainty (Folke et al. 2005, Fazey et al. 2007), scholars have not yet clearly articulated appropriate learning approaches and outcomes during periods of social-ecological change (Armitage et al. 2008). Monitoring and evaluation frameworks that focus on collaboration tend to overlook the role of learning (see, for example, Innes and Booher 1999, Anderies et al. 2004, but see Plummer and Armitage 2007), and indeed collaboratively monitoring the learning processes of initiatives is novel in the field of natural resource management, where the vast majority of collaborative monitoring efforts are aimed at monitoring ecological variables (see, for example, Moller et al. 2004, Andrianandrasana et al. 2005, Poulsen and Luanglath 2005, Stuart-Hill et al. 2005). This paper therefore explores the characteristics of processes that promote learning in adaptive comanagement, and also aims to test a methodology for monitoring these in a collaborative way.

\section{Conceptual basis for monitoring social learning}

A shift in worldviews, perceptions, and behavior are widely accepted outcomes of collaborative processes (Connick and Innes 2001, Daniels and Walker 2001, Conley and Moote 2003, Sims and Sinclair 2008). However, social learning approaches actively seek these outcomes through a reflexive process that encourages participants to question accepted modes of behavior or belief, and to reflect and adapt (Keen et al. 2005, O'Donaghue 2007). Social theories of learning define learning as active social participation in the practices of a community (Lave and Wenger 1991, Wenger 1998), and emphasize the dynamic interaction between people and the environment in the construction of meaning and identity (Muro and Jeffrey 2008). A 'community of practice' refers to a group or groups of people who share a concern for something that they do, and learn how to do it better through regular interaction (Wenger 1998). Three basic elements of communities of practice (Wenger 2000) are: i) There is a sense of joint enterprise that brings people together; ii) members interact and learn with one another through an ongoing history of mutual engagement; and iii) a capability of practice, or a shared repertoire of resources is developed, for example, lessons learned, rules of thumb, vocabulary, and standards. This repertoire reflects the community's accumulated knowledge.

Argyris (1999, as cited in Keen et al. 2005) refers to single-, double-, and triple-loop learning, which offers insight into institutional innovation as an outcome of learning processes. Single-loop learning refers to improving actions, strategies, and practices, which generally occurs within a project team engaged in 'conventional' adaptive management (Walters 1986, Margoluis and Salafsky 1998). Double-loop learning involves questioning the assumptions and mental models that underpin the selection of particular strategies and actions. This is particularly important in collaborative processes where different forms of knowledge and mental models come together. Triple-loop learning occurs when the values and norms that underpin these assumptions are questioned and reflected upon, which leads to a deeper understanding of the context, power dynamics, and values that influence the capacity to manage natural resources (Keen et al. 2005). Therefore, when the goal of collaboration is collective action and institutional innovation, as is the case in transitions toward adaptive 
comanagement, the institutional outcomes of collaboration can usefully be understood through the lens of social learning. Table 1 summarizes criteria for processes that promote collaboration on the one hand (Column A), and social learning on the other (Column B). The criteria for social learning extend the criteria for collaborative processes by focusing attention on the ways in which perceptions, values, and beliefs shift through collaborative processes, and therefore the ways in which institutional innovation potentially occurs.

However, monitoring social learning and the formation of communities of practice remains a significant challenge. Scholars have argued that a small set of key variables tend to be dominant in observed system change, and that by identifying this small set of key variables important changes in systems can be understood (Walker et al. 2006). This potentially holds true when monitoring learning processes because a set of contextual factors influence the ways in which social learning takes place during collaborative efforts and whether or not communities of practice form (Michael 1995, Wenger 1998, Ison 2005, Wals 2007). A generally agreed upon precondition for social learning is that multiple meanings, understandings, and realities are acknowledged (Ison 2005, Fazey et al. 2007, Plummer and Armitage 2007). This is related to the need to create arenas for collaboration, trust building, and the willingness of participants to listen to alternative viewpoints (Pretty 2003, Olsson et al. 2004b, Armitage 2005, Kumler and Lemos 2008). Acknowledging uncertainty and creating opportunities to learn from errors requires procedures that embrace error (Michael 1995). This allows for adaptation and therefore resilience. However, in order to achieve this within adaptive comanagement, sufficient funding is necessary to enable monitoring and timely responses (Olsson et al. 2004a). Conflict is part of collaboration and learning (Lee 1993), and needs to be facilitated by an 'honest broker' who is concerned with encouraging a learning process, rather than being focused only on the outcomes of an initiative (Michael 1995, Brown et al. 2005). Table 2 summarizes these 'preconditions' for collaboration and learning, which can be regarded as the key variables that influence the ability of role players to engage in the social learning processes outlined in Table 1.

This introduction has highlighted the conceptual foundations for monitoring the collaborative and learning processes followed in adaptive comanagement.
In the next section the question of 'how' these conceptual insights might be used in monitoring is addressed.

\section{STUDY AREA AND METHODS}

Three case studies were selected, all of which are located in South Africa (Table 3), and received funding from the national environmental agency between 2005 and 2008 to initiate comanagement between the affected communities and the state. All case studies had the same international agency acting as the 'implementing agent' on behalf of national government. The initiatives were designed to foster the creation of partnerships and knowledge networks, and to provide training and capacity building in various aspects of comanagement, conflict management, and monitoring and evaluation (Mitchell et al. 2008). This common design played a crucial role in the selection of the case studies because the goals resonate strongly with those of adaptive comanagement. The case studies were also selected to provide the maximum contextual variation between sites, to draw general conclusions about the significance of observed trends in the processes observed (Flyvbjerg 2006). The fieldwork component of this study involved two parallel research approaches: collaboratively monitoring the key variables that influence social learning (Table 2), and qualitatively evaluating social learning processes based on the criteria summarized in Table 1.

\section{Monitoring key variables}

Collaborative monitoring activities took place over the course of 18 months between June 2006 and December 2007 in Machubeni, Nqabara, and Riemvasmaak (Table 3). Monitoring activities took place with the committees that had been elected by their respective communities for the purposes of the comanagement initiative, and therefore did not need to be reselected for this research process. In all cases these bodies stressed equal representation of women and men, and of the youth and the elders.

Monitoring took the form of rating systems that were administered during focus group workshops and semistructured discussions (Borrini-Feyerabend 1997). Simple outcome indicators in the language of each community concerned were developed 
Table 1. Process criteria for evaluating collaboration and social learning.

A. Process criteria for collaboration (Innes and Booher 1999)

All relevant interests are included in the process

The process is driven by shared concerns and a purpose that is of real concern to the group

The process should be self-organizing, and allow participants to identify the ground rules, objectives, tasks, and topics of concern

Participants should be engaged and interested in the process, taking part in in-depth discussions and informal interactions

The process should challenge the status quo and encourage creative thinking about problems and their solutions

Accurate and meaningful information should be available, and its meaning should be agreed upon by all actors
B. Process criteria for social learning (adapted from Keen et al. 2005, O'Donaghue 2007, Wals 2007)
Situating and engaging: Key actors are identified and issues of concern or problems to be solved are identified with these actors in a way that is sensitive to the local context and their past experiences

Awareness raising, enquiry, and deconstruction: recognizing different worldviews and understandings of a problem, and being aware of one's own frames of reference in relation to a problem. Clarifying and challenging one's own and other's frames of reference

Cocreating: developing shared frames of reference for understanding the problem based on exposure to alternative worldviews, and visioning about 'what could be'

Practical action and experimentation: translating ideas that emerge from the previous steps into collaborative actions based on the cocreated frames of reference, and testing the applicability of these to meet the challenges identified Reflection: assessing the degree to which issues of concern and challenges have been addressed, and also the ways in which frames of reference have been changed as a result of experience based on the key variables identified in Table 2. The outcome indicators were rated four times during the year at each site, roughly four months apart in each site, each corresponding to a monitoring event. In Riemvasmaak, the third event was cancelled because of poor coordination within the committee involved. In this case three monitoring events took place, but over the same time frame as the other sites.

For each indicator, a rating of 1 (minimum, 'strongly disagree') to 5 (maximum, 'strongly agree') was agreed upon by the group, and an explanation for each rating was provided (Table 2). Participants used the indicators to evaluate whether the conditions necessary for social learning had changed over the preceding three to four months. The project advisory and steering committees (PASC), typically between 15 and 35 people, divided into smaller groups with mixed gender and age classes wherever possible, typically between three and six people, and then reported back to the whole group on ratings applied to each statement. Debates then ensued over the appropriate rating for a given indicator within the larger group. An important goal of the monitoring exercise was to elicit and discuss points of contention, and to grapple with differing interpretations of 'how well comanagement is going'. Once a rating had been agreed and the explanation provided, an action was identified that could improve the situation. At the end of each monitoring event, of which there were four in each site, except in Riemvasmaak where there were three, one rating was agreed upon for each indicator. Therefore, at the end of the 18 month monitoring process, there were 3-4 ratings applied to each of the indicators in each site.

\section{Data analysis}

Trends were analyzed qualitatively because the limited number of data points excluded the use of typical Lickert Scale analysis techniques. The sum of the ratings attached to each outcome indicator was divided by the number of monitoring events during the 18 months to give an average rating for each indicator. Overall positive or negative change was discerned by comparing the first and final ratings attached to an indicator. 
Table 2. Key variables and outcome indicators for collaborative monitoring. Each indicator was rated according to a 5 point scale $(5=$ strongly agree; $1=$ strongly disagree) and an explanation was provided by participants (Key variables adapted from Lee 1993, Michael 1995, Wenger 2000, Pretty 2003, Olsson et al. 2004a, Armitage 2005, Brown et al. 2005, Kumler and Lemos 2008)

\begin{tabular}{|c|c|c|c|}
\hline Key variables & Indicators for monitoring & $\begin{array}{c}\text { Rating } \\
1-5\end{array}$ & Explanation \\
\hline
\end{tabular}

Trust building

Trust building is taking place between the groups involved in collaborative decision making - Decision making is perceived as open and fair. Information is shared and understood by all participants.

Groups with shared norms and a common interest who have a similar stake in ecosystem management

Economic or other incentives to participate

Security of tenure over the resources of concern

Security of access to resources - There is long term

A perceived value in sharing information

A willingness to engage in collaborative learning and decision making

Sufficient funding to enable practical action and experimentation security of access to resources. The decision making body is confident that they are/will be able to prevent outsiders from using the resources.

There is a common interest and shared vision Participants jointly identify and agree on the problems to be solved, and what the future should look like. It is clear to all participants why a decision making body is needed. Participants agree on what the major problems are, and what the benefits might be of resolving these problems.

Incentives: People who contribute more are rewarded, and people who loose ways of earning a living because of the project are compensated.

Participants recognize the value of sharing information between actors - The organization or people from the community and from outside the community. These actors respect one another and listen to each other's points of view.

All participants are willing to engage in collaborative learning and decision making - All actors, from outside and inside the community, listen to each other and are willing to change what they are doing in response. 'Experts' are willing to learn from resource users, and resource users are open to alternative ways of doing things. The project is viewed as a learning process by everyone involved.

A long term investment has been made - The state or its partners are committed to making a substantial and long term financial investment in the project. Long term skills and leadership development programs are in place, and planning and decision making support is offered. committee involved in the initiative is made up of 
Social networks that allow effective information flow
Networks are established that connect the local decision making body with other institutions- Outside partners, such as government officials, researchers and NGO's are involved and are willing to devolve decision making powers. Other, relevant, local decision making bodies are consulted and included in decision making. The roles of these different actors are clearly defined.

Information flow - There is good communication between everyone involved. People are informed about what is happening, and their views and opinions are listened to

$\begin{array}{ll}\text { Effective local } & \text { Leadership - The leaders of the initiative care about } \\ \text { leadership or an 'honest } & \text { more than just their own interests. The leaders are }\end{array}$ broker' to facilitate trusted and acknowledged by all actors conflict resolution

\section{Qualitatively evaluating process}

Parallel to the collaborative monitoring activities described above, the research design included a qualitative component aimed at testing the efficacy of the indicators used for monitoring. This approach was consistent with analytical approaches used to investigate the process of collaborative management (Plummer 2006), social learning and institutional innovation (Kumler and Lemos 2008), and the learning outcomes of participatory resource management and public engagement (Bull et al. 2008, Sims and Sinclaire 2008).

Qualitative approaches require a level of flexibility on the part of the researcher in terms of the methods used, but also require quality assurance of the evidence thus produced (Yin 1994). All discussions arising from the formal monitoring events were stored in a database developed using Microsoft Access, along with the dates and places where discussions took place to ensure that evidence could be traced. Fieldwork notes taken during or directly following interviews, workshops, and observations were dated and stored in site specific files stating the date, time, and place of the discussion, the names of informants and their relationship to the initiative being discussed. Regular stakeholder meetings where results were reported further assured the quality and integrity of results.

Key informant interviews took place concurrently with community leaders, district and provincial government officials involved in or responsible for the initiatives, and with consultants involved in implementing the initiatives. These interviews were combined with participant observation (Jorgensen 1989, Cohen et al. 2000) during collaborative meetings between different actors, and also during monitoring workshops where debates and discussion ensued over points of contention. Observations were directed toward learning interactions, defined as any formal or informal situation in which learning takes place. Examples include workshops, meetings, and conversations (Downsborough 2007). The conceptual framework used to guide observations was drawn from the collaborative (Innes and Booher 1999) and social learning literature (Keen et al. 2005, O'Donaghue 2007, Wals 2007).

\section{RESULTS}

\section{The collaborative strategy adopted in all sites}

Overall, the collaborative strategy adopted by the implementing agent met the criteria for collaborative processes (Column A in Table 1). In all three sites, PASCs were created as a means to improve communication between the multiple stakeholders involved, and included representatives from the implementing agent and contractors, provincial and local government, NGO's, community institutions, and a representative from each of the villages that made up each community. 
Table 3. Case study summaries.

\begin{tabular}{|c|c|c|c|}
\hline & Machubeni & Nqabara & Riemvasmaak \\
\hline Location & $\begin{array}{l}\text { Emalahleni Local Municipality, } \\
\text { Eastern Cape }\end{array}$ & $\begin{array}{l}\text { Mbashe Local Municipality, } \\
\text { Eastern Cape }\end{array}$ & $\begin{array}{l}\text { Siyanda District Municipality, } \\
\text { Northern Cape }\end{array}$ \\
\hline Land tenure & Communal & Communal & Communal \\
\hline Population & 7344 & 3369 & 780 \\
\hline Land area affected & 16,150 ha & 1500 ha & 75,000 ha \\
\hline Land use & $\begin{array}{l}\text { Crop cultivation, livestock } \\
\text { farming, brick making, grass } \\
\text { harvesting }\end{array}$ & $\begin{array}{l}\text { Crop cultivation, livestock } \\
\text { farming, harvesting of forest } \\
\text { products }\end{array}$ & $\begin{array}{l}\text { Limited livestock farming, } \\
\text { tourism }\end{array}$ \\
\hline $\begin{array}{l}\text { Objectives of } \\
\text { intervention }\end{array}$ & $\begin{array}{l}\text { Reinstate community access to } \\
\text { high quality drinking/irrigation } \\
\text { water } \\
\text { Improve the agricultural } \\
\text { production systems } \\
\text { Reverse the process of land } \\
\text { degradation } \\
\text { Stop further siltation of the dam } \\
\text { Create income from catchment } \\
\text { management } \\
\text { Design a model for integrated } \\
\text { catchment and natural resources } \\
\text { management by communities }\end{array}$ & $\begin{array}{l}\text { Support the establishment of a } \\
\text { community conservancy } \\
\text { through: } \\
\text { The rehabilitation and } \\
\text { restoration of the natural } \\
\text { landscape } \\
\text { Upgrade and construct facilities } \\
\text { for conservancy } \\
\text { Incorporate a craft production } \\
\text { centre, office, and meeting } \\
\text { venue/workplace } \\
\text { Identify, rehabilitate, and } \\
\text { prepare a site for lodge } \\
\text { development }\end{array}$ & $\begin{array}{l}\text { Create a community conservancy } \\
\text { on land formerly owned by } \\
\text { National Parks Board } \\
\text { Develop conservation and } \\
\text { tourism services capacity } \\
\text { Job creation in the conservation } \\
\text { and tourism sectors } \\
\text { Involve communities in } \\
\text { combating desertification and } \\
\text { managing land }\end{array}$ \\
\hline
\end{tabular}

The PASCs played a guiding, advisory and sometimes decision making role. The PASCs were also aimed at improving relationships between the various project partners by creating a forum for conflict management and discussion. The community component of the PASCs played a critical communication role between the project management team and the larger community. Community representatives on the PASCs were expected to regularly inform their constituencies about the progress of the initiatives. The PASCs met monthly in each site.

A mechanism was therefore created through which all relevant stakeholders could be included within the process (Column A in Table 1). A shared purpose was clearly identified in the form of a set of aims or vision. However, the shared purpose did not necessarily imply shared concerns. Since the initiatives were founded strongly on democratic principles, the community participants on the PASCs were elected to sit on the PASC, rather than having volunteered to participate through a sense of real concern. In addition, the PASC meetings were held on a prearranged monthly basis and were initiated by outside actors, which inhibited selforganization within the group.

The ground rules, objectives, and tasks of the PASCs were decided by the contractors and implementers prior to their creation, although some room was available to adjust the agenda of each meeting. On the whole, the PASC meetings acted as 'information days' in which project activities 
were reported. Although the monthly meetings did not allow reflection on the degree to which challenges had been addressed, they did result in the sharing of accurate and relevant information between all actors. Therefore, although this collaborative strategy met the criteria for effective collaboration in complex systems, it was not deliberately designed to promote social learning.

\section{Case studies - qualitative evaluation of social learning}

Case studies presented in this section are analyzed according to the criteria for social learning presented in Table 1 (Column B).

\section{Machubeni}

The PASC in Machubeni was formed in a vacuum of institutional capacity for natural resource management that was reflected in the absence of rules governing access to communal resources such as grazing land and water. However, by the end of the initiative, Machubeni displayed evidence of triple loop learning, which resulted in institutional innovation that incorporated redundancy at multiple levels.

Situating, engaging, awareness raising, and cocreating. A great deal of investment was made in social facilitation in this site. The initiative as a whole was preceded by participatory land use planning and visioning workshops in which community members were encouraged to imagine 'what could be' and ways of achieving this. This visioning process was used to guide the intervention in this site, and the vision was revisited throughout the initiative.

Practical action and experimentation. A core group of locally recognized 'experts' in land management was identified by the PASC to receive specialist training in land management, the development of management plans, indicator development, and natural resource monitoring. This group became a subcommittee of the larger body, and became a hub for innovation. Within six months of the subcommittee being formed, their consultations with village headmen and community members had lead to the suggestion of creating 'village land committees' that were based on a form of management with which local people were familiar and comfortable, and incorporated forms of both traditional and democratic governance norms.

Figure 1 illustrates the design of the Machubeni Section 21 Company, a legally recognized not for profit organization, that was eventually formed out of this process. The structure was based equally on the PASC model, a growing recognition of the need for cross-scale collaboration, and on locally appropriate norms in decision making that respected the autonomy of villages to create their own rules under the guidance of the larger body, which is akin to the traditional relationship between headmen, who operate at the level of the 'community', and subheadmen, who operate at village level. The structure was designed to ensure communication from the village level to local and district government departments, and also to ensure that traditional leaders were fully integrated into decision making processes at all levels. As a result, a degree of redundancy was integrated into the design, because the relative autonomy of the lower levels meant that rule creation and enforcement could take place at both the village and the executive board level.

Reflection. The process in Machubeni was characterized by almost constant contestation, questioning, reflection, and surprise. Indeed, the Section 21 Company was formed amid a great deal of conflict. Power dynamics within the community led to a situation in which only one of the initial members of the PASC who received training and experience in land management and collaborative decision making was voted onto this legal body during the crucial change-over phase when the PASC became legally recognized. This was due to infighting and jealousies between previously elected members of the PASC and formal and traditional leaders who felt sidelined by the initiative. This has caused a capacity shortage within the body.

\section{Nqabara}

A Development Trust, a legally recognized, not for profit organization, already existed in Nqabara prior to the initiative, and therefore the emphasis during the collaborative process was placed on the contractual obligations of the project, including infrastructure development for tourism facilities, rather than questioning underlying values and norms and therefore institutional design. Although 
Fig. 1. The Machubeni Section 21 Company.

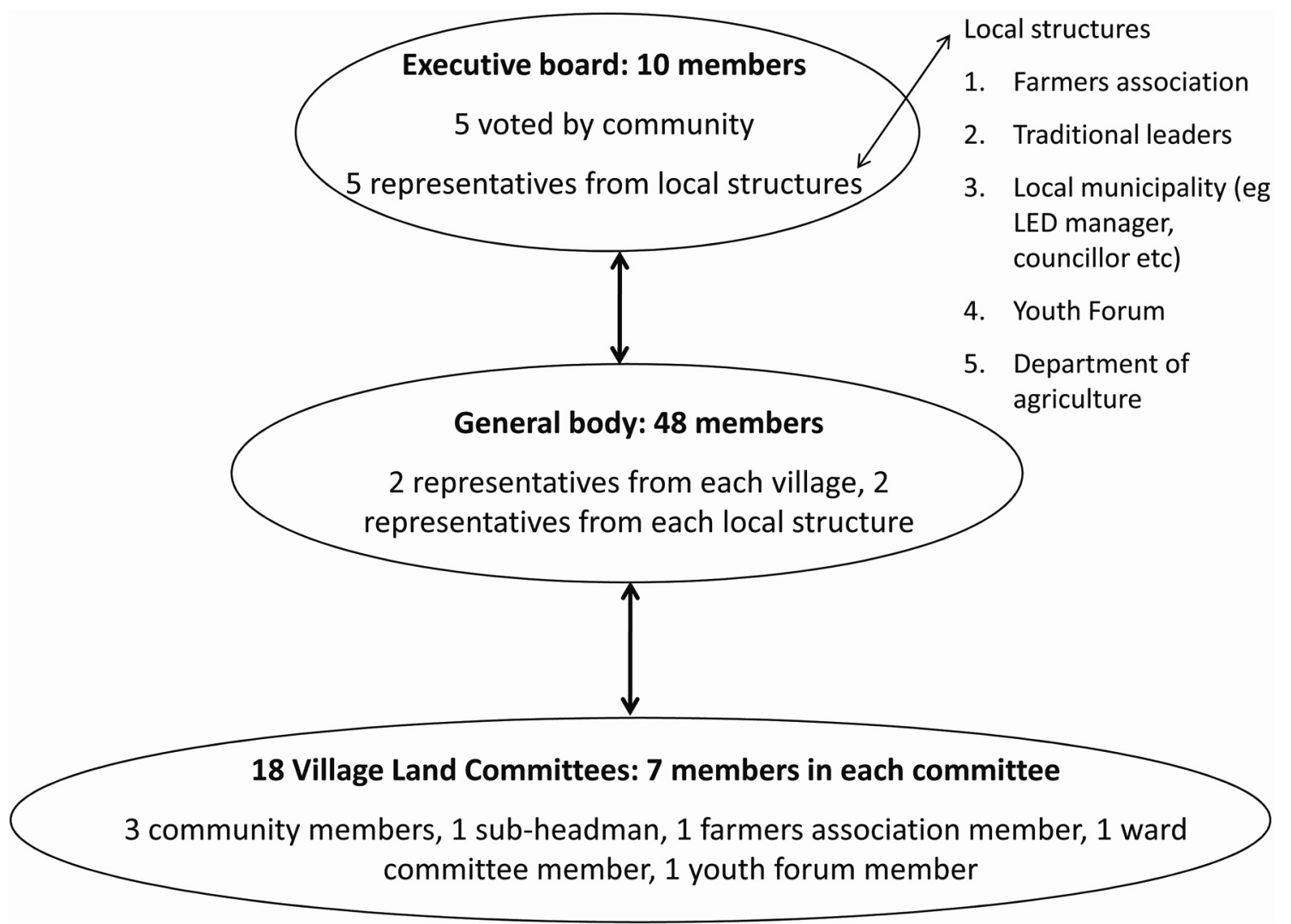

the collaborative process was not characterized by institutional innovation, it was characterized by the formation of an effective community of practice.

Situating, engaging, awareness raising, and cocreating. The PASC in Nqabara was formed against the backdrop of over seven years of forestry comanagement. The international agent was very active in this site both before and during the initiative, and several years previously had brought in professional conflict resolution experts to train the Development Trust in dealing with conflict. The Nqabara Development Trust formed the community component of the PASC. Over the years, the Trust was populated by the same individuals who had initially been voted onto the Trust several years previously because subsequent elections had never taken place. One of the reasons for this was that Trust members felt that benefits might be forthcoming in the future, and since they had already invested so much time in the body, they wanted to benefit if that time ever came. Indeed, as time went on and the promise of benefits became more real, members of the Trust wanted less and less to question the status quo. The amount of time spent working together on land management issues over the years meant that a sense of common purpose, a capability of practice, and a shared understanding of problems was developed within the Trust.

Practical action and experimentation. A number of collaborative challenges faced the PASC which both encouraged and undermined innovation and action. Firstly, political rivalries between the elected Councilor for the Ward and the chairperson of the Trust meant that this Councilor would not attend PASC meetings, and actively withheld applications from the Trust to the municipality for services such 
as piped water for a community nursery. This lead to a great deal of animosity:

[we have witnessed] the emergence of two opposing camps. The Councilor is currently on the opposite side to the members of the Trust, and does not attend meetings.... comments like 'we'll kill the councilor' are not helping matters, but demonstrate the seriousness of the situation.

(Facilitator, Ruliv, February 2007, personal communication)

Although the conflict was not resolved, the Trust members did develop a means of getting around this difficulty, and eventually bypassed the councilor and took applications directly to the relevant officials within the municipality. This indicates that the Trust was effectively identifying problems, finding solutions, and taking action. Secondly, by the time of the initiative, the Trust had been negotiating comanagement agreements for state owned forests for over seven years, with very little being achieved in that time. Although government officials blamed their superiors for not providing guidance on this issue, the Trust generally felt that the government did not trust them enough to hand over decision making authority

Reflection. The status quo of the membership of the Trust was not reflected upon or challenged during the process. The long tenureship of the members of the Development Trust meant that the organization had become increasingly rigid and therefore vulnerable because all of the learning and experience was concentrated in a small set of key individuals. Were elections to be held in Nqabara, there is a danger that the accumulated learning and experience of this group would be lost.

\section{Riemvasmaak}

Active trust building did not take place at Riemvasmaak, and the initiative lacked consistent outside input and facilitation because the contractor hired for the day-to-day implementation of the initiative was a local resident. Throughout, the politics of the Development Trust, which had been extant for 10 years prior to the comanagement intervention considered here, and conflicts between the two settlements that make up the community tended to dominate decision making.
Situating, engaging, awareness raising, and cocreating. The development of shared frames of reference for understanding the challenges facing the community was undermined by a number of factors. Firstly, the remoteness of the site, situated $54 \mathrm{~km}$ from the nearest town on an unpaved road, meant that attendance of PASC meetings by key stakeholders in the municipality was very low. Secondly, members of the Trust sat on the PASC, but unlike Nqabara, they were joined by elected community members who did not sit on the Trust, and the simmering hostilities between the Trust and the community at large influenced the ability of these two parties to reach a common understanding. Thirdly, democratic processes were well entrenched in the community, and elections took place every two years for the Development Trust. These election processes further undermined the development of shared frames of reference for understanding problems because membership changed every two years.

Practical action and experimentation. The lack of outside facilitation in this site also meant that there was little room for institutional adjustment or experimentation. From the community's perspective, this was because they were unaware of their legal options and did not have access to the information they needed in order to make informed decisions:

We don't know what our options are: how do we make the Trust accountable? The Trust has not held a community meeting in two years. But there is a lot of nepotism, so certain families support the Trust no matter what.

(PASC member, Riemvasmaak, February 2007, personal communication ).

The general distrust both within the community and between the community and outside agencies undermined the ability of the PASC to translate ideas into shared action for which everyone took responsibility.

Reflection. Reflection and active criticism were common features of the collaborative process in Riemvasmaak. However, a feeling of helplessness in the face of the challenges that were identified was equally salient. This feeling of helplessness stemmed largely from a lack of access to information and sound advice, which in turn was 
partly a product of there being no active facilitator or 'honest broker' involved in the initiative.

\section{Monitoring outcomes: trends in key variables}

Although Riemvasmaak indicated a number of negative trends or no change in key variables affecting social learning, Machubeni and Nqabara reported only positive or no changes in key variables (Table 4). When compared with the narrative accounts just presented, this suggests that collaborative monitoring is robust enough to track social learning over time.

Trust building received high average ratings because the monthly PASC meetings were considered successful in encouraging dialogue between actors and in dealing with misunderstandings that might otherwise have lead to conflict. In Riemvasmaak low ratings were given on average because of poor attendance of government officials at the PASC meetings, and also because of growing discontent between community elected members of the PASC and the representatives of the Development Trust who sat on the PASC. The Trust members were consistently accused of not communicating with the community at large.

The existence of a common interest within groups received high average ratings in all sites. Participants identified the fact that community participants attended the monthly PASC meetings voluntarily, and indeed incurred personal expenses in doing so, as evidence of the common interest. In Machubeni the comparatively low ratings for this variable were due to the fact that although there was a common vision and everyone was working toward this vision, participants felt they were "not there yet. , Although positive trends were reported for incentives for collective action, this indicator received the lowest average ratings across all sites. A range of reasons were provided for these low ratings, but generally revolved around the fact that members of the PASCs were not paid or compensated for travel costs to attend meetings, despite some having to travel up to 20 kilometers without transport of their own. Other issues related to households who had lost access to land or resources during the initiatives. The following statement was typical:

One wood cutter out of nine in total is compensated [for losing access to the forests] by getting a job [through the comanagement initiative]. The rest aren't compensated. The [Development] Trust members do not benefit, in fact they cannot benefit because it is laid down in the constitution.

(Member of the Development Trust, Nqabara, November 2006, personal communication).

Where positive trends in incentives were reported, these reflected actions taken to provide travel stipends, although this did not occur in Riemvasmaak. The indicator for tenure security was high or improved during the initiatives, except in Riemvasmaak where a negative trend was reported because of the ongoing and increasingly hostile negotiations with government over access to a piece of land belonging to the community. The high average ratings reflect the belief that the land 'belongs to the people' rather than an ability to exclude outsiders or enforce rules governing the use of the land, as reflected in the following statement:

We know that the forests are ours, we are secure in our ownership, but we don't have the power to enforce rules because we never get recognition from $D W A F$ [Department of Water Affairs and Forestry]. We have ownership but we don't have power. (Development Trust member, Nqabara, June 2007, personal communication)

The indicator for the perceived value in sharing information with different stakeholders received high ratings and a general improvement was identified in Nqabara. The perceived value and willingness of stakeholders to share information and to learn are reflected in the following statement made during monitoring exercises:

People from outside the community listen
more than the locals, but people do also
listen locally. For example, even though the
rules developed in the management plans
have not been formalized or enforced,
people are already following them.
(PASC member, Machubeni, March 2007 ,
personal communication)

The willingness of stakeholders to engage in collaborative learning and decision making was modest, except in Riemvasmaak, where positive trends were reported. Challenges facing collaborative 
Table 4. Average ratings and trends in key variables that influence collaboration and social learning.

\begin{tabular}{lccc}
\hline \hline Variable & Machubeni & Nqabara & Riemvasmaak \\
\hline Trust building & $5 \uparrow$ & $4 \uparrow$ & $2--$ \\
Groups of common interest & $3--$ & $4 \uparrow$ & $5 \uparrow$ \\
$\begin{array}{l}\text { Economic or other incentives } \\
\text { for collective action }\end{array}$ & $3 \uparrow$ & $3 \uparrow$ & 1 -- \\
$\begin{array}{l}\text { Security of tenure over the } \\
\text { resources of concern }\end{array}$ & $4--$ & $4--$ & $4 \downarrow$ \\
$\begin{array}{l}\text { A perceived value in sharing } \\
\text { information }\end{array}$ & $4--$ & $4 \uparrow$ & $5--$ \\
$\begin{array}{l}\text { A willingness to engage in } \\
\text { collaborative decision } \\
\text { making }\end{array}$ & $4 \uparrow$ & $4 \uparrow$ & $3 \uparrow$ \\
$\begin{array}{l}\text { Sufficient funding to enable } \\
\text { practical action and } \\
\text { experimentation }\end{array}$ & $4 \uparrow$ & $4 \uparrow$ & \\
$\begin{array}{l}\text { Social networks that allow } \\
\text { effective information flow }\end{array}$ & $4--$ & $4 \uparrow$ & $4 \downarrow$ \\
$\begin{array}{l}\text { Effective local leadership/ } \\
\text { 'honest broker' }\end{array}$ & & 4 & 4 \\
\hline
\end{tabular}

$\uparrow$ Indicates improvement in the variable over time, $\downarrow$ Indicates a decline in the variable over time, -Indicates no change in the variable over time

decision making across sites are reflected in the following statements made during monitoring in Machubeni and Riemvasmaak:

Some consultants do not listen to the community. They do not respect the ideas of the community. There is also a need to build respect between traditional leaders and the community [so that they will listen to each other]

(PASC member, Machubeni, November 2006, personal communication)
We have a problem with the municipality, theynever attend meetings. But the problem now is within the community, while in the past it was between the community and outsiders. People are no longer listening to one another

(Riemvasmaak, November 2007, personal communication).

Ratings attached to access to long term funding for management were generally high, primarily because of the large sums of money that had already 
been allocated to the initiatives, but also because of future planning that was already underway. Social networks that allow the effective flow of information received average overall ratings and displayed a mixture of positive and negative trends. In Riemvasmaak the negative trend was once again due to dissatisfaction with the Development Trust. In Nqabara, initial low ratings were due to a lack of municipal participation in PASC meetings and the failure of researchers from universities to report back on their findings. Positive trends were due to report backs having taken place, and the election of a 'social coordinator' in the community through whom all meetings were arranged by outside actors. In Machubeni, average ratings were given because although people were encouraged by the formation of the PASC, there was a feeling of not being on an equal footing with other stakeholders, as reflected in the following statement:

\section{Sometimes the agreements are not honored, people from outside bring changes but don't keep promises. [For example] the fields that were taken away from some people for [soil] rehabilitation. They never received compe- nsation. \\ (PASC member, Machubeni, September 2007, personal communication)}

Positive trends in effective leadership were indicated in Machubeni and Nqabara, but not in Riemvasmaak. The positive trend in Machubeni reflected the growing involvement of traditional and elected leaders in the PASC, whereas in Nqabara the positive trend reflected the attendance of the local councilor at PASC meetings toward the end of the initiative.

\section{Common factors undermining social learning across sites}

Leakages of human capital, i.e., skills and experience, out of the system were a feature of all sites, and this occurred in a variety of ways. Firstly, although there was a strong emphasis on formal capacity development in the form of training courses in each of the case studies, in many instances these skills 'leaked' out of the communities. In Riemvasmaak, for example, people who are skilled are expected to leave the community and find work in the surrounding centers:

\begin{abstract}
Our culture tells us that those who are skilled must leave the community and find work elsewhere. They are expected to send money home.

(Community member, Riemvasmaak, personal communication).
\end{abstract}

In Machubeni, emigration of skilled people was identified as a major challenge facing development in their area. As an example, both of the community members employed as local project administrators have subsequently found permanent employment outside of Machubeni.

Skills are also lost through the ways in which democratic structures operate. In Riemvasmaak, the Development Trust is re-elected every two years. Those who are elected are frequently unskilled. The result is that every two years the Trust must learn leadership and management skills, financial management skills, and generally require a period of trust building within themselves, and between themselves and local government officials. After two years the cycle restarts. A similar trend occurred in Machubeni, where the first election process ushered in an entirely new set of leaders with little or no background in land management and collaborative decision making.

\section{DISCUSSION}

The value of viewing collaboration through the lens of social learning when monitoring adaptive comanagement is highlighted by the fact that although all of the case studies followed identical collaborative strategies through the formation of PASCs and monthly meetings, the learning processes varied significantly from site to site. The lens of social learning, in which knowledge is considered to be contextual and embedded within local histories, cultures, and the ways in which these are experienced by individuals (Ison 2005, Fazey et al. 2007), is compatible with that of complexity thinking, which stresses the role of the socialecological context (Balee 1998, Adger 1999) and system memory (Folke et al. 2003) in influencing outcomes.

There appeared to be correspondence between the direction of change in key variables, and the social learning processes followed. Where the key variables for social learning showed mostly positive 
trends (Table 4), social learning and institutional innovation appeared to be more pronounced, such as Machubeni and Nqabara. Conversely, where the key variables such as trust building and incentives for participation were considered to be low, the evidence of social learning processes being followed was less pronounced, such as Riemvasmaak. These results have two implications. Firstly, they suggest that the conditions necessary for social learning can be externally managed during an initiative, with positive outcomes for learning processes and potentially innovation, and therefore transitions toward adaptive comanagement. Secondly, they suggest that the small set of key variables (sensu Walker et al. 2006) identified in this study (Table 2), provide a useful starting point for monitoring social learning as part of adaptive comanagement.

In Machubeni, high levels of careful and well funded facilitation yielded positive conditions for social learning, and the institutional outcomes represented shifts in local rule making that were based on recurring questioning and contestation of traditional decision making structures and processes. This implies that triple loop learning also took place during the collaborative process (Keen et al. 2005). In Nqabara, by contrast, comparatively less focus was placed on creating the conditions necessary to achieve this, and indeed many collaborative challenges were faced, and yet the monitoring activities identified equally positive learning conditions to Machubeni (Table 4). Learning, it seems, occurs through two parallel processes: the first through formally designed learning interactions (Keen et al. 2005), and the second through experience over time (Ison 2005, Berkes and Turner 2006).

A comparison of the processes followed and the outcomes observed in Machubeni, Nqabara, and Riemvasmaak demonstrates that facilitation by an 'honest broker' (Michael 1995, Brown et al. 2005) is critical to social learning in situations where the possibility of conflict is high. Although Machubeni and Nqabara received dedicated funding and ongoing support from professional facilitators, Riemvasmaak did not and the process was facilitated by a local community member. The absence of an impartial facilitator, against the backdrop of conflict and historical distrust evident in that site, offers some explanation for the differences in outcomes observed.
Although the same collaboration strategy was adopted in all three sites, through the creation of the PASCs, the ways in which participation actually occurred in each site varied significantly, as did the learning processes. In each case the local context and 'institutional memory' or pre-existing institutional structures (cf. Berkes and Folke 2002, Folke et al. 2003) influenced active questioning of the status quo. Context and memory therefore matter (Fazey et al. 2007). These findings suggest that long term interactions with a core group of individuals to build 'positive memory' should be encouraged during collaborative efforts. There does not appear to be a substitute for experience, but carefully facilitated interactions that are sensitive to the social-ecological context are equally vital.

Democratic decision making in Machubeni and Riemvasmaak, although essential for transparency and good formal governance, undermined the creation of long term communities of practice in two important ways. Firstly, people were elected, rather than joining out of a real and shared concern, which is essential for the formation of communities of practice (Wenger 1998). Secondly, rotating election processes effectively removed individuals from the bodies after a certain amount of time. A similar situation has been described in Namibia, where learning was undermined by election cycles (StuartHill et al. 2005). These formal processes of election and rotation in the PASCs potentially undermined self-organization within the groups.

Although the act of devolving decision making responsibilities to communities illustrates a desire for a more democratic society, real questions about the appropriateness of this model must be raised. Enforcing more formalized resource management regimes such as those characterized by Section 21 companies and Development Trusts, in addition to democratic principles, on resource-poor communities is a double edged sword that can undermine collaboration and learning in natural resource management. In Machubeni, the very effective 'coup' of the decision making structure by an entirely different set of individuals, after the investment of large amounts of time and money in training and capacity building in the original group, demonstrates this danger.

However, although democratic processes pose a threat to ongoing learning, a lack of broad participation can result in rigidity and vulnerability in decision making structures, as indicated by the 
case of Nqabara. One option for the maintenance of experience and learning within decision making bodies, while allowing for change, is the rotation of only a proportion of the membership during any given election cycle. In this way, the learning that has taken place can be maintained and shared with new members, ensuring continuity during transitions.

Our findings suggest that the available criteria for social learning do not help explain the observed institutional innovation that was an outcome of the collaborative processes observed in some of the case studies. Triple loop learning does however offer insight into the processes involved in this innovation and can usefully be combined with the social learning criteria to understand outcomes, provided the two theories of learning are not conflated.

In historically disadvantaged areas with low levels of human capital and weak infrastructure, the facilitation challenges to promote effective social learning should not be underestimated. A particular challenge is the balancing of power. The knowledge of powerful individuals tends to dominate in rural areas, and facilitators and academics have to therefore intervene with great care and sensitivity. It is furthermore challenging to implement rigorous programs of reflection and learning because of practical challenges such as transport, poor communication, and the day to day challenges of making a living in remote areas. For social learning to be effective, there is a need for ongoing long term assistance by skilled facilitators. This adds an additional practical challenge, which could be addressed through the training of resident facilitators.

\section{CONCLUSION}

Traditionally, the collaborative literature stresses a change in worldviews and behavior as positive outcomes of the collaborative process but is not explicit about 'how' this might take place. Social learning theory sheds light on the ways in which the perceptions, values, and beliefs that underpin behavior and assumptions shift through collaborative processes, and therefore the ways in which innovation occurs. Shifts in local rule making and enforcement in the case studies were based on recurring questioning and contestation of traditional decision making structures and processes. Under the resource poor conditions of the case studies explored here, and throughout the developing world, this innovation can be critical to initiating and maintaining transitions toward adaptive comanagement.

The results of this study suggest that for learning to be effective, a balance needs to be sought between maintaining key individuals within the system, preventing rigidity and vulnerability when this is achieved, and encouraging active participation within communities of practice. Effective facilitation by an 'honest broker' is one of the ways in which this can be achieved. A growing interdisciplinary dialogue among educationalists will contribute substantially toward finding this balance (Fazey et al. 2007).

It is also important to note that concepts such as communities of practice and situated learning sit uncomfortably beside concepts of learning through multilevel networks, which is one of the basic assumptions underpinning adaptive comanagement. The 'partners' in these networks will seldom have the same stake in locally based natural resource management and are seldom willing to share power. This challenge holds the potential to undermine adaptive comanagement, and deserves greater attention in the future.

Collaborative monitoring created spaces in which collaboration and learning could take place during the initiatives. Although this represents an obvious challenge to researchers who seek to track change in social-ecological systems because they will themselves become agents of change, this reality of complex systems research also points to the potential role that collaborative monitoring can play in initiating positive transitions. The small set of key variables identified and tested in this study were sensitive enough to capture changes in social learning, and could therefore form the basis for future research into social learning.

Responses to this article can be read online at: http://www.ecologyandsociety.org/vol15/iss3/art28/ responses/ 


\section{Acknowledgments:}

The author would like to thank Christo Fabricius for very useful comments and insights provided on this paper. Financial support from the Centre for Scientific and Industrial Research (CSIR), DAAD, GTZ Transform and the Andrew Mellon Foundation is gratefully acknowledged.

\section{LITERATURE CITED}

Adger, W. N. 1999. Evolution of economy and environment: an application to land use in lowland Vietnam. Ecological Economics 31:365-379.

Anderies, J. M., M. A. Jansson, and E. Ostrom. 2004. A framework to Analyse the Robustness of Social-ecological Systems from an Institutional Perspective. Ecology and Society 9(1):18. [online] URL: http://www.ecologyandsociety.org/vol9/iss1/ art18/.

Andrianandrasana, H. T., J. Randriamahefasoa, J. Durbin, R. Lewis, and J. H. Ratsimbazafy. 2005. Participatory ecological monitoring of the Alaotra wetlands in Madagascar. Biodiversity and Conservation 14:2757-2774.

Argyris, C. 1999. On organisational learning. Blackwell Business, Malden, Massachusetts, USA.

Armitage, D. 2005. Adaptive capacity and community based natural resource management. Environmental Management 35:703-715.

Armitage, D., F. Berkes, and N. Doubleday. 2007. Introduction: moving beyond co-management. Pages 1-15 in D. Armitage, F. Berkes, and N. Doubleday, editors. Adaptive co-management: collaboration, learning, and multi-level governance. University of British Colombia Press, Vancouver, British Colombia, Canada.

Armitage, D., M. Marschke, and R. Plummer. 2008. Adaptive co-management and the paradox of learning. Global environmental change 18:86-98.

Armitage, D. R., R. Plummer, F. Berkes, R. I. Arthur, A. T. Charles, I. J. Davidson-Hunt, A. P.
Diduck, N. Doubleday, D. S. Johnson, M. Marschke, P. McConney, E. Pinkerton, and E. Wollenberg. 2009. Adaptive co-management for social-ecological complexity. Frontiers in Ecology and the Environment 6:95-102.

Balee, W. 1998. Advances in historical ecology. Columbia University Press, New York, New York, USA.

Berkes, F., and C. Folke. 2002. Back to the future: ecosystem dynamics and local knowledge. Pages 121-144 in L. Gunderson, and C. S. Holling, editors. Panarchy: understanding transformations in human and natural systems. Island Press, Washington, D.C., USA.

Berkes, F., and N. J. Turner. 2006. Knowledge, learning and the evolution of conservation practice for social-ecological system resilience. Human Ecology 34:479-494.

Borrini-Feyerabend, G. 1997. Beyond fences: seeking social sustainability in conservation. IUCN, Kasparek Verlag, Gland, Switzerland.

Brown, V., M. Keen, and R. Dyball. 2005. Lessons from the past, learning for the future. Pages 247-265 in M. Keen, V. Brown, and R. Dyball, editors. Social learning in environmental management: towards a sustainable future. Earthscan, London, UK.

Bull, R., J. Petts, and J. Evans. 2008. Social learning from public engagement: dreaming the impossible? Journal of Environmental Planning and Management 51:701-716.

Capra, F. 2007. Foreword. Pages 13-15 in A. Wals, editor. Social learning: towards a sustainable world. Wageningen Academic Publishers, Wageningen, Netherlands.

Cohen, L., L. Manion, and K. Morrison. 2000. Research methods in education. Routledge, London, UK.

Conley, A., and M. Moote. 2003. Evaluating collaborative natural resource management. Society \& Natural Resources 16:371-386.

Connick, S., and J. Innes. 2001. Outcomes of collaborative water policy making: applying complexity thinking to evaluation. Institute of Urban 
and Regional Development, University of California at Berkeley, California, USA.

Daniels, S., G. B. Walker. 2001. Working through environmental conflict: the collaborative learning approach. Paeger, Westport, Connecticut, USA.

Doubleday, N. 2005. From dialectic to praxis: adaptive co-management as midwife to change? In Canada's Oceans: Research, Management and the Human Dimension. Proceedings of the Ocean Management Research Network National Conference, 28 September-October 2005, Ottawa, Ontario, Canada. [online] URL: http://www.omrn-rrgo.ca/?a ction=conferences $2005 . \sec 33$.

Downsborough, L. 2007. Social learning processes in a citrus farming community. Rhodes University, Grahamstown, South Africa.

Fazey, I., J. A. Fazey, J. Fischer, K. Sherren, J. Warren, R. Noss, and S. Dovers. 2007. Adaptive capacity and learning to learn as leverage for socialecological resilience. Frontiers in Ecology and Environment 5:375-380.

Flyvbjerg, B. 2006. Five misunderstandings about case-study research. Qualitative Inquiry 12:219-245.

Folke, C., J. Colding, and F. Berkes. 2003. Synthesis: building resilience and adaptive capacity in social-ecological systems. Pages 352-387 in F. Berkes, J. Colding, C. Folke, editors. Navigating social-ecological systems: building resileince for complexity and change. Cambridge University Press, Cambridge, UK.

Folke, C., T. Hahn, P. Olsson, and J. Norberg. 2005. Adaptive governance of social-ecological resources. Annual review of environment and resources 30:441-473.

Innes, J., and D. Booher. 1999. Consensus building and complex adaptive systems: a framework for evaluating collaborative planning. Journal of the American Planning Association 65:412-425.

Ison, R. 2005. Traditions of understanding: language, dialogue and experience. Pages 22-40 in M. Keen, V. Brown, and R. Dyball, editors. Social learning in environmental management: towards a sustainable future. Earthscan, London, UK.
Jorgensen, D. 1989. Participant observation: A methodology for human studies. Sage Publications, London, UK.

Keen, M., T. Bruck, and R. Dyball. 2005. Social learning: a new approach to environmental management. Pages 3-21 in M. Keen, V. Brown, R. Dyball, editors. Social learning in environmental management: towards a sustainable future. Earthscan, London, UK.

Kumler, L. M., and M. C. Lemos. 2008. Managing waters of the Paraíba do Sul river basin, Brazil: a case study in institutional change and social learning. Ecology and Society 13(2): 22. [online] URL: http://www.ecologyandsociety.org/vol13/iss2/ art22/.

Kristofferson, A. H., and F. Berkes. 2005. Adaptive co-management of arctic char in Nunavut Territory. Pages 249-268 in F. Berkes, R. Huebert, H. Fast, M. Manseau, and A. Diduck, editors. Breaking ice. University of Calgary Press, Calgary, Alberta, Canada.

Lave J., and E. Wenger. 1991. Situated learning: Legitimate peripheral participation. Cambridge University Press, Cambridge, UK.

Lee, K. 1993. Compass and gyroscope: integrating science and politics for the environment. Island Press, Washington, D.C., USA.

Margoluis, R., and N. Salafsky. 1998. Measures of Success. Island Press, Washington, D.C., USA.

Marschke, M., and Nong, K. 2003. Adaptive comanagement: lessons from coastal Cambodia. Canadian Journal of Development Studies XXIV (3):369-383.

McConney, P., R. Mahon, and R. Pomeroy. 2007. Challenges facing coastal resource co-management in the Caribbean. Pages 105-124 in D. Armitage, F. Berkes, and N. Doubleday, editors. Adaptive comanagement: collaboration, learning and multilevel governance. University of British Columbia Press, Vancouver, British Columbia, Canada.

Michael, D. 1995. Barriers and bridges to learning in turbulent human ecology. Pages 461-485 in L. Gunderson, C. S. Holling, and S. Light, editors. Barriers and bridges to the renewal of ecosystems 
and institutions. Columbia University Press, New York, New York, USA.

Mitchell, D., L. Coelho, J. Baumgart, and $\mathbf{H}$. Snel. 2008. Lessons learnt from implementing community based natural resource management projects in South Africa. Training and Support for Resource Management (TRANSFORM) Programme, GTZ. Pretoria, South Africa.

Moller, H., F. Berkes, P. O'Brian Lyver, and M. Kislalioglu. 2004. Combining science and traditional knowledge: monitoring populations for co-management. Ecology and Society 9:(3): 2. [online] URL: http://www.ecologyandsociety.org/vol9/ iss3/art2.

Muro, M., and P. Jeffrey. 2008. A critical review of the theory and application of social learning in participatory natural resource management. Journal of Environmental Planning and Management 51:325-344.

O'Donaghue, R. 2007. Environment and sustainability education in a changing South Africa: a critical historical analysis of outline schemes for defining and guiding learning interactions. Southern African Journal of Environmental Education 24:141-157.

Olsson P., C. Folke, and T. Hahn. 2004a. Socialecological transformation for ecosystem management: the development of adaptive co-management of a wetland landscape in Southern Sweden. Ecology and Society 9(4): 2. [online] URL: http://www.ecol ogyandsociety.org/vol9/iss4/art2/.

Olsson P., C. Folke, F. Berkes. 2004b. Adaptive co-management for building resilience in socialecological systems. Environmental Management 34:75-90.

Olsson, P., L. H. Gunderson, S. R. Carpenter, P. Ryan, L. Lebel, C. Folke, and C. S. Holling. 2006. Shooting the rapids: navigating transitions to adaptive governance of social-ecological systems. Ecology and Society 11(1): 18. [online] URL: http: //www.ecologyandsociety.org/vol11/iss1/art18/.

Olsson, P., C. Folke, V. Galaz, T. Hahn, and L. Schultz. 2007. Enhancing the fit through adaptive co-management: creating and maintaining bridging functions for matching scales in the Kristianstads Vattenrike Biosphere Reserve Sweden. Ecology and Society 12(1): 28. [online] URL: http://www.e cologyandsociety.org/vol12/iss1/art28/.

Ostrom, E. 1990. Governing the commons: the evolution of institutions for collective action. Cambridge University Press, Cambridge, UK.

Ostrom, E. 1992. Institutions as rules-in-use. Pages 19-39 in E. Ostrom, editor. Crafting institutions for self-governing irrigation systems. ICS, San Francisco, California, USA.

Pahl-Wostl, C. 2006. The importance of social learning in restoring the multifunctionality of rivers and floodplains. Ecology and Society 11(1): 10. [online] URL: http://www.ecologyandsociety.org/voll1/ iss1/art10/.

Parson, E. A., and W. C. Clark. 1995. Sustainable development as social learning: theoretical perspectives and practical challenges for the design of a research program. Pages 428-460 in L. Gunderson, C. S. Holling, and S. Light, editors. Barriers and bridges to the renewal of ecosystems and institutions. Columbia University Press, New York, New York, USA.

Plummer, R. 2006. Sharing the management of a river corridor: a case study of the co-management process. Society \& Natural Resources 19:709-721.

Plummer R., and D. Armitage. 2007. A resilience based framework for evaluating adaptive comanagement: linking ecology, economics and society in a complex world. Ecological Economics 61:62-74.

Poulsen, M. K., and K. Luanglath. 2005. Projects come, projects go: lessons from participatory monitoring in southern Laos. Biodiversity and Conservation 14:2591-2610.

Pretty, J. 2003. Social capital and the collective management of resources. Science 302:1912-1914.

Ruitenbeek, J., and C. Cartier. 2001. The invisible wand: adaptive co-management as an emergent strategy in complex bio-economic systems. CIFOR, Bogor, Indonesia.

Sims, L., and A. J. Sinclair. 2008. Learning through participatory resource management programs: Case studies from Costa Rica. Adult Education Quarterly 58:151-168. 
Stuart-Hill, G., R. Diggle, B. Munali, J. Tagg, and D. Ward. 2005. The event book system: a community-based natural resource monitoring system from Namibia. Biodiversity and Conservation 14:2611-2631.

Walker, B., L. Gunderson, A. Kinzig, C. Folke, S. Carpenter, and L. Schulze. 2006. A handful of heuristics and some propositions for understanding resilience in social-ecological systems. Ecology and Society 11(1): 13. [online] URL: http://www.ecolog yandsociety.org/vol11/iss1/art13/.

Wals, A. E. J. 2007. Learning in a changing world and changing in a learning world: reflexively fumbling towards sustainability. Southern African Journal of Environmental Education 24:35-45.

Wals, A., and T. van der Leij. 2007. Introduction. Pages 17-32 in A. Wals, editor. Social learning: towards a sustainable world. Wageningen Academic Publishers, Wageningen, Netherlands.

Walters, C. 1986. Adaptive management of renewable resources. MacMillan, New York, New York, USA.

Wenger, E. 1998. Communities of practice: learning, meaning, and identity. Cambridge University Press, Cambridge, UK.

Wenger, E. 2000. Communities of practice: the structure of knowledge stewarding. Pages 205-224 in C. Despres, and D. Chauval, editors. Knowledge horizons: the present and the promise of knowledge management. Butterworth-Hieneman, Boston, Massachusetts, USA.

Yin, R. 1994. Case study research: design and methods. Sage, London, USA. 